\title{
Jihad e escravidão: as origens dos escravos muçulmanos da Bahia
}

\author{
Paul E. Lovejoy
}

Cabe-se que a configuração étnica da população baiana modificou-se sig$\checkmark$ nificativamente nas últimas décadas do século XVIII e ao longo do seguinte, quando Hauçás, Nupes e outros povos islamizados tornaram-se comuns entre os escravos, em especial a partir dos volumosos desembarques de cativos de fala Ioruba no século XIX. ${ }^{1}$ As origens desses escravos muçulmanos podem estar relacionadas ao contexto próprio das áreas interioranas da Baía de Benin e à jihad do Xeque Usman dan Fodio (morto em 1817), fundador do Califado de Sokoto. Deste modo, este estudo examina o material biográfico disponível, em uma tentativa de oferecer subsídios adicionais acerca da comunidade muçulmana para, assim, estabelecer mais claramente as ligaçóes entre os padrōes de resistência à escravidão na Bahia, que culminaram na insurreição Malê de 1835, e o movimento da jihad no interior da Baía de Benin.

Em um estudo anterior examinei 108 indivíduos cuja escravização no interior daquela zona foi seguida de sua migração para a Bahia ou, pelo menos, tinha-se tal destino em pauta. ${ }^{2}$ A ele foram acrescentadas outras biografias, do que derivou uma amostragem agora redefinida para 117 indivíduos originários do Sudão Central (veja-se o apêndice), região interiorana em relação à Baía de Benin que compreendia zonas de savana e parte do sahel, e que caiu sob dominação do Califado de Sokoto no século XIX. Por certo, nem todas estas pessoas desembarcaram na Bahia, e algumas acabaram em Serra Leoa, por exemplo. ${ }^{3}$ Contudo, o grau de concentração da população escrava islamizada da Bahia permite-me supor que as características dos cativos libertados em Serra Leoa, e de outros que não alcançaram o Brasil, são representativas dos padrões históricos mais amplos, transferidos para solo baiano através da jihad; embora, é claro, reinterpretados pelas condiçôes locais. 
A associação entre a jih ad e a população muçulmana deslocada para o Brasil constitui-se em um tema complexo, do qual nos aproximamos aqui, como já se disse, por meio do exame das histórias de vida de indivíduos escravizados no Sudão Central. Conforme discutido em outro trabalho, a eclosão da Guerra Santa muçulmana, em 1804, sucedeu a um período de turbulências políticas que eram, em parte, caudatárias de reações à escravização de muçulmanos que alegavam ser livres, e sua exportação para as Américas. ${ }^{4}$ Contudo, longe de pôr termo à escravização e à exportação de islâmicos, aparentemente a jihad teve por efeito a disseminação do câncer do cativeiro, com freqüência vitimando pessoas que imaginavam que a submissão ao Islã poderia protegê-las da deportação para além-mar. Por outro lado, até mesmo muitos opositores da Guerra Santa que se encontravam escravizados voltaram-se para o Islã militante no Brasil, promovendo a causa revolucionária da jihad como forma de obter maior autonomia ou a liberdade. A grande extensão do Islã militante na Bahia derivava do fato de que os muçulmanos enviados para as Américas encontravam-se ali fortemente concentrados. É possível que de 100 a 150 mil escravos do Sudão Central (excluídos os Iorubas setentrionais) tenham cruzado o Atlântico entre meados do Setecentos e a primeira metade do século XIX. Tal estimativa inclui os cativos identificados como Hauçás, Nupes, Bornos, Borgus e outras designaçóes que indicam uma origem ao norte da Iorubalândia. De 75 a 124 mil destes escravos partiram entre 1800 e 1850, com a grande maioria dirigindo-se, sem dúvida, para o Brasil, especialmente para a Bahia. ${ }^{5}$ Os identificados como "Iorubas do norte" (i.e., Oyo, Ekiti, Yagba e Okun Ioruba) também estavam bem representados na população exportada ${ }^{6}$ e, embora ainda não seja possível calcular o número de Iorubas setentrionais, estes eram certamente numerosos. Por conseguinte, nossa análise vai além do foco mais antigo representado pelas populaçóes Hauçá, Nupe e Borno, ainda que as estimativas da escala da migração forçada de áreas afetadas pela jihad de Sokoto não incluam os Iorubas. Com esta perspectiva mais ampla, tenta-se capturar as áreas nas quais a jihad estava sendo levada a cabo até meados do Oitocentos.

Apesar dos dados não serem conclusivos, pode-se dizer, em uma estimativa conservadora, que os escravos do Sudão Central constituíam de 10 
a 15\% dos escravos exportados pela Baía de Benin nas décadas de 1770 e 1780 , proporção que subiu nos anos 90 e ao longo da primeira década do século XIX, com a concomitante queda do número de escravos originários de áreas costeiras.

Em termos globais, é possível que 40 ou 50 mil escravos centro-sudaneses tivessem sido exportados pelo Atlântico no século XVIII. Após este período, a proporção de cativos originários daquela região, em relação ao total de exportados através da Baía de Benin, conheceu acentuadas flutuações. No início da década de 1810, na primeira metade dos anos 20 e durante a primeira parte da década de 30 do século XIX, quando as exportações globais da Baía de Benin foram relativamente baixas, os escravos do Sudão Central talvez representassem de 25 a $40 \%$ do total vendido. Em anos-pico de fins das décadas de 1810, 1820 e 1830, a proporção de centro-sudaneses provavelmente caiu para $15 \%$ do total das exportações da Baía de Benin. ${ }^{7}$ Nestas ocasiōes, a quantidade de Iorubas era grande, em especial a de Iorubas meridionais.

\section{As origens étnicas dos escravos do Sudão Central}

A maioria dos escravos que vieram do Sudão Central, no século XVIII, chegou à Baía de Benin através de Oyo. Comerciantes muçulmanos da região sudânica eram muito ativos naquela área já na primeira década do Setecentos, quando traziam escravos, panos e marfim à costa em troca de álcool, cauris e outros bens. ${ }^{8}$ Por volta de meados do século, escravos Hauçás eram comuns em Oyo, tanto para uso doméstico quanto militar. ${ }^{9}$ Nas décadas de 1780 e 1790, à margem deste mercado doméstico, as reexportações de cativos centro-sudaneses para as Américas através de Oyo (por meio de seus portos ao longo da "Costa dos Escravos") parecem ter crescido, em resposta à demanda americana por fontes adicionais de cativos. De fato, Porto Novo emergiu como o principal porto de Oyo, e seu comerciante mais importante nos anos 80 e 90, Pierre Tamata, um antigo escravo de origem Hauçá que fora educado na França, chegou a viajar para o Brasil. ${ }^{10}$ Neste período, poucos cativos, se é que os havia, foram exportados do Sudão Central através da Baía de Biafra ou da Costa de Ouro. ${ }^{11}$ 
A jihad foi responsável por uma proporção significativa das exportações da Baía de Benin depois de 1804, embora estas estivessem em níveis muito mais baixos do que em décadas pretéritas. A rota para a costa continuou atravessando Oyo pelo menos até inícios da década de 30 do século XIX, mas a crescente insegurança, relacionada à própria jihad, interferia nas trocas. O Baixo Rio Níger tornou-se, portanto, uma rota alternativa para o litoral, ao mesmo tempo em que outros escravos passaram a ser conduzidos através da principal rota leste-ocidental para o país Achanti - a mais importante fonte de nozes de kola, um estimulante amplamente consumido. Escravos enviados a Achanti por certo bem poderiam ser reexportados para os portos da Baía de Benin; desde a imposição da abolição pela Inglaterra, depois das 1807, as feitorias da Costa de Ouro não puderam continuar a exportar cativos.

As exportações de escravos da Baía de Benin totalizaram 75 mil cativos na primeira década do século XIX — o mais baixo nível observado naquela região em mais de 100 anos —, mas a parcela originária do Sudão Central parece ter aumentado significativamente. Em 1806, a Baía de Benin supria a Bahia com 8.307 indivíduos "Gege [Ewe/Fon/Gbe], Usa [Hauçá] e Nagô [Ioruba]". ${ }^{12}$ Embora as proporçōes de cada uma destas categorias étnicas não sejam conhecidas, é possível que, em função das guerras de Sokoto, os Hauçás constituíssem uma parte significativa delas. ${ }^{13} \mathrm{~A}$ importância da jihad na geração de escravos entre 1804 e 1810 será atestada mais adiante, por meio das biografias de cativos que haviam sido capturados nas guerras santas, como no caso daqueles entrevistados por d'Andrada na Bahia em 1819. A concentração de escravos Hauçás em território baiano data deste período.

Os escravos provenientes do Sudão Central continuaram figurando de forma significativa no comércio Atlântico da Baía de Benin depois de 1810, como reflexo da expansão da jihad, além da insurreição muçulmana do exército de Ilorin em 1817, a guerra de Owu no início dos anos 20, as revoltas que arruinaram Oyo nesta mesma década, as guerras de Nupe de 1822 a 1856 e a malograda insurreição islâmica ocorrida em Borgu (1835). A mal sucedida incursão do Califado à costa, em 1843, demonstra seu contínuo interesse nas áreas meridionais, e a jihad sempre resultava na es- 
cravização de pessoas em áreas próximas à Baía de Benin. Uma amostragem de 177 escravos, de quatro diferentes navios negreiros datados do período 1821-1822, inclui 41 Nupes, 34 Hauçás e um Fulani — os quais perfazem $43 \%$ dos cativos cujas origens étnicas eram especificadas. ${ }^{14} \mathrm{Tal}$ amostragem parece ter sido típica somente da primeira metade do anos 20. Em fins desta década e do decênio seguinte, os escravos Iorubas entraram em quantidades expressivas e, ao longo destes períodos, o número de escravos centro-sudaneses declinou em termos relativos, embora ainda representasse uma proporção significativa das exportaçôes globais.

No primeiro terço do século XIX, escravos Hauçás, Nupes e Bornos, além de alforriados, constituíam parcela importante da população baiana. De acordo com Reis, pelo menos 15,8\% de todos os escravos e ex-escravos da Bahia, em meados da década de 30 do século XIX, tinha vindo do Sudão Central. Reis examinou registros relativos a cativos libertos entre $1819 \mathrm{e}$ 1836, e de escravos urbanos de 1820 a 1835 (1.341 casos). Entre aqueles cujas origens étnicas eram conhecidas (2.431 indivíduos), 385 indivíduos eram originários do Sudão Central, dos quais 252 eram Hauçás (10,3\%), 88 eram Nupes (3,6\%) e 45 provinham de Borno (1,8\%). Se os Iorubas lançados no tráfico pelas guerras implementadas pelo Califado de Sokoto forem incluídos neste total, a proporção de cativos centro-sudaneses, resultante da crescente expansão da jihad naquela região, aumentará ainda mais. Escravos Iorubas e libertos constituirão 28,6\% da amostragem de Reis (699 pessoas), ${ }^{15}$ e parece provável que muitos, senão a maioria deles, resultavam direta ou indiretamente da jihad. Dado que índices desta magnitude só podiam ser alcançados como conseqüência de uma forte importação de cativos durante as duas ou três décadas anteriores a 1835, os escravos do Sudão Central devem ter constituído uma proporção significativa das exportações de cativos da Baía de Benin naquele momento.

$\mathrm{Na}$ realidade, embora não refletidas nos registros baianos, as origens étnicas dos escravos centro-sudaneses eram complexas. Algumas indicações desta complexidade podem ser capturadas a partir de um inventário lingüístico efetuado em 1850, em Serra Leoa, pelo missionário e lingüista alemão Sigismund Wilhelm Koelle. Ele coletou o vocabulário de ex-escravos, muitos dos quais originários da Baía de Benin, e identificou indivíduos que 
poderiam falar Igala (13), Nupe e idiomas correlatos (303), línguas de Borno (36), Buduma (1), Fika (5), Karekare (2), Bede e Ngizim (16), Hauçá (8), e um número desconhecido de Fulani entre ex-escravos do Sudão Central. ${ }^{16}$ Os Hauçás estavam claramente sub-representados nesta amostragem.

Koelle estava tentando identificar tantos idiomas quanto possível, e por isso detectou e enumerou proporçôes menores das comunidades lingüísticas maiores. No censo de Serra Leoa de 1848 havia 657 Hauçás e 163 Nupes, em uma população total de 13.273 ex-escravos. ${ }^{17}$ É provável que houvesse pelo menos 1.200 pessoas do Sudão Central em Freetown em 1850 — quase $10 \%$ da população. Embora a amostragem de Koelle não possa ser usada para estabelecer a importância relativa das diferentes categorias étnicas da população escrava exportada de origem centro-sudanesa, o inventário revela que grandes categorias como Hauçá, Nupe e Borno incorporavam pessoas que não necessariamente teriam sido identificadas como tais no Sudão Central. ${ }^{18}$

Muitos Iorubas foram escravizados na jihad que se disseminou pelo sul, por Oyo e pela região norte-oriental Ioruba depois das 1817, especialmente nas décadas de 20 e 30 do século XIX. É difícil mensurar a quantidade de escravos Iorubas resultantes da guerra santa islâmica, embora os recentes estudos de Francine Shields e Femi Kolapo indiquem que a jihad teve um papel fulcral em muitas áreas. ${ }^{19}$ As guerras "Iorubas", responsáveis pela envergadura das exportações de escravo da Baía de Benin nos anos 30 e 40, estiveram relacionadas à jihad de Sokoto. O Emirado de Ilorin, que possuía uma grande população Ioruba, interveio nas guerras entre seus vizinhos sulistas, e neste processo foram feitos muitos escravos Ioruba. ${ }^{20}$ Além disso, os emirados Nupes invadiram cidades e aldeias Iorubas setentrionais. Por conseguinte, muitos Iorubas tiveram o seu cativeiro relacionado à expansão e consolidação do Califado de Sokoto e, portanto, podem ser contados entre os escravos originados no curso da jih ad no Sudão Central.

\section{0 perfil sexual da população escrava exportada}

Analisando inventários de plantações do Caribe francês do século XVIII, David Geggus detectou uma alta incidência — por ele chamada de 
"excepcional" - de homens Hauçás em relação a mulheres da mesma origem, as quais deteriam uma participação "muito menor que a de outras mulheres que entraram nas Américas através do tráfico atlântico" ${ }^{21}$ Entre os escravos listados nos registros franceses de Saint Domingue, 532 eram de origem Hauçá, Nupe e Bariba - 444 homens e 88 mulheres, ou seja, os homens constituíam $83 \%$ dos cativos registrados como originários do Sudão Central. Dos 287 Hauçás, 207 (94\%) eram do sexo masculino. ${ }^{22}$ Geggus não oferece dados sobre as origens étnicas de outros cativos centro-sudaneses e, embora seus números derivem de fontes francesas, é provável que os Hauçás importados na mesma ocasião pela Bahia conhecessem proporções sexuais semelhantes. O significado disso pode ser capturado através da comparação com as taxas de masculinidade, mais equilibradas, observadas em outras categorias étnicas em Saint Domingue, conforme análise do próprio Geggus: os Hauçás detinham as mais altas taxas de masculinidade observadas entre as categorias étnicas importadas de toda a África, e não apenas da Baía de Benin. A categoria étnica com taxa de masculinidade mais próxima era a dos Nupes, com 76\% dos 161 escravos registrados. Os escravos Bariba também apresentavam uma grande taxa de masculinidade — aproximadamente $61 \%$.

O predomínio de homens era especialmente marcante no século XIX. De acordo com Clapperton (1824), o Califado de Sokoto especializou-se em exportar homens para as Américas e, em sua avaliação, "a maior parte dos escravos masculinos jovens era levada para o sul e comercializada na Baía de Benin”. ${ }^{23}$ A preponderância de homens também foi reconhecida no Brasil, por Francis de Castelnau, que entrevistou 23 homens Hauçás na Bahia, em fins da década de 1840. Tratava-se de prisioneiros de guerra que viviam entre muitos outros cativos Hauçás: "la plupart sont employés à Bahia comme nègres de palanquin". Praticamente não havia mulheres e, de fato, "il est au contraire tres rare d'y rencontrer des femmes de leur nation". ${ }^{24}$

De acordo com James Richardson, que estava em Zinder, a mais ocidental província de Borno, em 1851,

os melhores escravos vão agora para Niffee [Nupe], para serem embarcados para as Américas; examinados minuciosamente antes da partida, são prin- 
cipalmente homens de segunda, terceira e quarta classe... [ou seja, os com]...começo de barba...[os]...sem barba...[e as]...crianças crescidas. ${ }^{25}$

Como Tambo concluiu em seu estudo sobre o comércio escravo do Califado de Sokoto, os

homens jovens compreendiam a vasta maioria dos que se destinavam ao sul [a partir do Califado de Sokoto]. Quase toda a região do Califado parece ter contribuído para este comércio. ${ }^{26}$

Perfis biográficos de escravos destinados à venda a traficantes europeus entre 1805 e 1850 atestam cabalmente ter sido masculina quase toda a população exportada. Em nossa amostragem de 117 cativos, só sete eram mulheres (cinco adultas e duas meninas). Esta alta freqüência de homens não é de todo surpreendente, dada a tendência de coletar informação sobretudo de indivíduos do sexo masculino. Contudo, a própria dificuldade em localizar mulheres centro-sudanesas na população escravizada, sugere que as proporções de homens na nossa amostragem talvez não estejam longe do padrão prevalecente. Há outros exemplos, e talvez não seja gratuito que Christopher Fyfe tenha detectado, para Freetown em 1837, que dois homens Hauçás ali estavam depois de terem sido emancipados em Trinidad; eles se mudaram para Badagri em 1839, junto com um homem Nupe. ${ }^{27}$

As mulheres, embora pouco numerosas, estavam majoritariamente em sua melhor idade. A maior parte delas — talvez as mais cobiçadas — eram exportadas do Sudão Central para o norte, através do Sahara, e não para o litoral da Guiné. O mercado de concubinas para moças bonitas e mulheres ainda jovens era bastante extenso no Norte da África, e mesmo no Sudão Central. ${ }^{28}$ É possível que poucas jovens tenham sido vendidas para o sul, e as que tiveram tal destino parecem ter sido aquelas acusadas de crimes graves, especialmente assassinato. Por conseguinte, creio que minha amostragem de 117 escravos reflete bem as taxas de masculinidade prevalecentes no tráfico do Sudão Central para as Américas. Ela confirma o trabalho de Eltis e Engerman, os quais demonstraram que as cargas humanas dos negreiros europeus que partiram da costa africana tenderam a apresentar taxas de masculinidade semelhantes, independentemente do lugar para o qual se destinassem nas Américas. ${ }^{29}$ Sua análise indica que o perfil etário-sexual 
dos escravos adquiridos pelos traficantes europeus na costa refletia-se de modo mais ou menos idêntico em todo o litoral, mas até agora não tem sido possível determinar com maior acuidade os perfis de idade e de sexo dos cativos que, provenientes do interior distante, chegavam a estas costas.

\section{Tabela 1:}

\section{Taxas (\%) de masculinidade dos escravos exportados pela Baía de Benin, 1800-1866}

\begin{tabular}{lccc}
\hline SEXO & TotAL & LiTORAL & INTERIOR \\
\hline Homens & 330,000 & $215,000-262,000$ & $71,000-118,000$ \\
Mulheres & 164,000 & $158,000-160,000$ & $4,000-6,000$ \\
Total & 497,000 & $373,000-422,000$ & $75,000-124,000$ \\
Taxas de Masculinidade & 67 & $58-62$ & 95 \\
\hline
\end{tabular}

Fontes: ELTIS, David. "Fluctuations in the Age and Sex Ratios of Slaves in the Nineteenth-Century Transatlantic Slave Traffic". In: Slavery and Abolition, 7, 1986, pp. 259, 264. As exportaçôes do Sudão Central são calculadas entre 75 mile 124 mil; cf. LOVEJOY, Paul E. "Central Sudan and Atlantic Slave Trade". In: HARMS, Robert W. et al. Paths toward the Past: African Historical Essays in Honor of Jan Vansina. Atlanta: African Studies Association Press, 1994, passim.

Minha amostragem de 117 escravos contribui para tornar possível a comparação etário-sexual entre os cativos exportados através do litoral africano e a população escrava proveniente do Sudão Central que se destinava às Américas (cf. tabela 1). Tal cotejo sugere que o Sudão Central contribuiu com uma proporção de homens maior do que a de qualquer outra região africana. Deste modo, embora os traficantes europeus demonstrassem um interesse de longo prazo em comprar escravos masculinos na melhor idade produtiva possível, a ação dos provedores africanos também teve um peso importante nas taxas etário-sexuais dos exportados e, por conseguinte, o padrão ideal de demanda européia por homens raramente foi satisfeito. ${ }^{30}$ Isto permitiu ao Sudão Central converter-se em uma fonte especializada de escravos masculinos em idade produtiva para o mercado americano. Como notou Eltis, 
as proporções de adultos masculinos entre os cativos Iorubas e Nupes na amostragem [de libertos] de Serra Leoa para 1821-1822 eram extremamente altas: para os Iorubas a taxa de masculinidade era de 61\% (263 casos), e para os Nupes alcançava 58\% (45 casos), todas elas referentes a escravos embarcados nos portos da Baía de Benin. ${ }^{31}$

Eltis não se deteve sobre os Hauçás e outras categorias étnicas, mas, como vimos, as taxas de masculinidade entre os cativos originários de áreas mais setentrionais eram ainda mais altas.

Escravos centro-sudaneses de sexo masculino foram detectados em diversas partes de África Ocidental. Os holandeses recrutavam homens na Costa de Ouro, inclusive cativos Hauçás, a fim de remetê-los para a Indonésia como soldados de seu exército colonial. ${ }^{32}$ Havia 95 escravos do Sudão Central entre os 1.170 cativos comprados por J. Heyducoper, feitor holandês na Costa de Capa entre 1837 e 1842, para posterior despacho ao exército colonial na Indonésia. $\mathrm{O}$ agente holandês foi mal-sucedido em sua intenção de adquirir os escravos que queria, pois o Asantehene Kwaku Dua não conseguiu (ou não quis) "produzir" cativos escravos na quantidade requerida pelo batavo. $\mathrm{O}$ recrutamento militar obviamente demandava apenas homens e, portanto, não era capaz de demonstrar a baixa freqüência de escravas centro-sudanesas no país Achanti. Mas os registros holandeses apontam para o fato de que nem todos os cativos de sexo masculino originários do Sudão Central eram exportados para as Américas. Deste modo, as estimativas referentes aos escravos centro-sudaneses que alcançaram as Américas não representam fielmente as exportações do Sudão Central como um todo.

Para o Daomé meridional e Lagos, ao longo da década de 1850, é possível encontrar indícios de que nem todos os homens adultos foram exportados para as Américas. Escravos registrados como tendo conseguido escapar de Whydah para Lagos em 1858 eram "na maioria dos casos... [provenientes]... em especial do interior da Hauçalândia e de Nuffee", e parece que muitos, senão todos, eram homens. ${ }^{33}$ Em Lagos, o Governador britânico, Glover, recrutava cativos Hauçás do sexo masculino, alguns dos quais fugitivos, para a força policial criada no nascente protetorado. ${ }^{34}$ Tais informaçôes acerca dos escravos fugitivos, das etnias dos libertos e do recruta- 
mento militar no país Achanti e em Lagos ajudam a montar um padrão no qual se reiteram homens centro-sudaneses, e demonstram de maneira aceitável que escravos homens em idade produtiva eram comuns na costa. Este perfil é congruente com o fato, bem conhecido, de que o tráfico atlântico era parte integrante do tráfico global endógeno à África. Dados desta natureza não permitem determinar com maior acuidade as taxas de masculinidade dos centro-sudaneses que não deixaram a África Ocidental, mas eles permitem intuir que os homens representaram uma grande parte deles. Afinal, como Clapperton observou em 1824, "a maioria" dos cativos homens em idade produtiva disponíveis para compra no Califado de Sokoto foi enviada à costa atlântica para exportação para as Américas. ${ }^{35}$

Portanto, as altas taxas de masculinidade observadas na população escrava exportada através da Baía de Benin na passagem do século XIX para o seguinte era, em grande medida, resultante da reexportação de escravos centro-sudaneses do sexo masculino, movimento que incluía a Iorubalândia setentrional durante o longo colapso de Oyo. Homens em idade produtiva provinham do interior em quantidades anormalmente altas, talvez porque o alto preço obtido pelos homens pudesse cobrir os custos de transporte do interior para o litoral, enquanto o custo do transporte de mulheres era geralmente muito maior no mesmo percurso, já que em termos gerais as escravas custavam um terço a mais do que os homens no interior. ${ }^{36}$ Não surpreende, pois, que a maioria das mulheres escravizadas e transportadas da Baía de Benin originavam-se de áreas relativamente próximas à costa. Em síntese, havia pelo menos dois componentes demograficamente distintos do tráfico na Baía de Benin: o primeiro, que trazia homens do interior distante para a costa, e o segundo, que sugava para fora da África escravos (homens, mulheres e crianças) do próprio litoral.

\section{0 perfil etário da população escravizada}

A maioria dos escravos de sexo masculino e das poucas mulheres exportadas pelo Sudão Central estava no auge de sua idade produtiva. De 100 cativos cujas idades podem ser estimadas, 83 (78 homens e cinco mulheres) eram adultos no momento da escravização. Outros oito, todos 
homens, tinham entre 16 e 18 anos. Só oito crianças — duas meninas e seis meninos - aparecem na amostragem, e a maioria dos homens adultos consistia em guerreiros capturados em campos de batalha, como pode ser visto na tabela 2 .

\section{Tabela 2:}

\section{Métodos de escravização de escravos de sexo masculino exportados do Sudão Central para a Costa Atlântica}

\begin{tabular}{lcc}
\hline MéTodo & NúMERO & PorCENTAGEM \\
\hline Guerra/jihad/pilhagem & 64 & 75 \\
Seqüestro & 15 & 17 \\
Ação judicial & 3 & 3 \\
Penhora & 3 & 3 \\
Venda de cativo doméstico & 1 & 1 \\
Escravo dado em pagamento de tributo & 1 & 1 \\
Sub-Total & 87 & 100 \\
Desconhecido & 30 & \\
Total & 117 & \\
\hline
\end{tabular}

Fonte: Apêndice.

De 87 escravos cujo método de escravização é conhecido, 64 (75\%) o foram através de guerras, pilhagens promovidas por Fulanis, ou por meio da jih ad propriamente dita. Outros 15 escravos (17\%) haviam sido seqüestrados, circunstância que poderia estar ou não relacionada à jih ad. Em alguns casos, a guerra parece ter estado relacionada a eventos secundários nas fronteiras do Califado de Sokoto. Portanto, tomados em conjunto, 92\% dos escravos informavam terem sido apresados de forma violenta. Esta alta porcentagem de escravização por meio da violência e a prevalência de homens adultos na população exportada é significativa. Homens em idade produtiva e com boa saúde também eram comuns entre os cativos provenientes da Iorubalândia setentrional, embora não entre os Iorubas como um todo. As guerras e pilhagems de Nupe e Ilorin talvez tenham sido res- 
ponsáveis por uma proporção significativa destes escravos. Em alguns casos os cativos haviam sido soldados, e outros eram clérigos muçulmanos, os quais freqüentemente se viam envolvidos com a jihad. Muitos cativos tinham conhecimentos ao menos rudimentares do árabe, e alguns eram na verdade muito instruídos, dado que também confirma a associação entre a jihad e o cativeiro. De fato, vários estudiosos demonstram que a associação entre pilhagems, ações militares e a jihad era freqüente. ${ }^{37}$

As observações de John Duncan, que estava em Whydah em meados da década de 40 do século XIX, confirmam a prevalência de homens adultos jovens entre a população cativa deportada do Sudão Central. Duncan detectou ainda que muitos dos escravos que voltaram do Brasil depois de 1835 eram originários do interior:

Sei que muitos deles foram mandados para longe do Brasil por haverem tentado fazer uma revolução [a revolta Malê de 1835] entre escravos [brasileiros], o que os colocou contra os seus senhores. Estes [escravos] era geralmente provenientes dos países Fula [o Califado de Sokoto] e Eyo [Oyo]. Muitos, aparentemente, foram capturados entre vinte e vinte quatro anos de idade, e podem oferecer ricas informações sobre o caminho para Badagri, de onde eles foram embarcados. ${ }^{38}$

Duncan também conheceu um homem de Borno que, enviado como escravo para a Bahia na mocidade, acabou por regressar a Borno e, à procura de sua casa, acabou descobrindo que sua cidade natal tinha sido destruída duas vezes durante a jihad. ${ }^{39}$

Escravizações judiciais e por penhora, vendas já sob a condição de cativos domésticos, e transferência como parte do pagamento de tributo povoam as trajetórias de cerca de $10 \%$ dos escravos cujas histórias de vida são conhecidas. Embora seja provável que muitas destas categorias não estivessem diretamente relacionadas à jihad, algumas das escravizaçôes por via jurídica e outras certamente se associavam à campanha muçulmana è̀ administração da justiça no Califado. Assim, entre as poucas mulheres enviadas para as Américas, havia escravas suspeitas de assassinato, como Clapperton observou em Kano, em 1824. De acordo com seu relato, concubinas foram acusadas de estrangular seu amo, um comerciante de Ghadames. Como resultado, acabaram deportadas para a costa, a fim de 
serem vendidas para as Américas. Ainda de acordo com Clapperton, tal caso era semelhante a dois ou três antes ocorridos. O governador de Kano, Ibrahim Dabo, indagou a Hadje Salah, chefe dos árabes, o que deveria ser feito numa ocasião como esta, se vender as cativas para fora do país, ou condená-las à morte. $\mathrm{O}$ comum nestes casos era enviar os criminosos à costa, para a venda a traficantes. ${ }^{40}$

Esta informação é importante pois trata-se da única referência a mulheres adultas, posto que concubinas, remetidas para a venda no litoral. A maioria das escravas ia para o norte através do Sahara, mas os "criminosos" constituíam uma categoria claramente separada. Há informações de que cativos "refratários e intratáveis" eram vendidos para a costa, mas nenhuma que mencione especificamente mulheres. ${ }^{41}$ Contudo, é provável que muitas das mulheres centro-sudanesas vendidas para o outro lado do Atlântico tenham se tornado escravas por meio de condenações, ou por suspeita de crimes graves. De acordo com um funcionário britânico em Serra Leoa, em 1821, "muitos nativos Hauçás, feitos prisioneiros pelos Foulahs [Fula, i.e., Fulani ou Fulbe] e trazidos por terra à Costa de Ouro, eram logo vendidos a traficantes europeus". ${ }^{42} \mathrm{O}$ escravo de Clapperton, Pasko, cujo nome muçulmano era Abubakar, era originário de Gobir; ele fora capturado durante a jihad, e de Katsina foi "vendido a um comerciante de Gonja", que então o vendeu a "um nativo Achanti", o qual logo o revendeu a um comerciante que ia para Whydah, onde ele finalmente foi embarcado em um navio português. ${ }^{43}$ Dan Kano, cujo nome indicava que sua mãe era de Kano, "nasceu em Brinee Yawoori [Birnin Yauri] e por lá permaneceu por aproximadamente dezesseis ou dezessete anos" (ou seja, antes de 8 de abril de 1821). Ele fora capturado pelos Fulani durante uma expedição comercial "e levado à Costa de Ouro", onde foi vendido a um navio português, muito provavelmente na Baía de Benin. ${ }^{44}$ As fontes de Koelle incluíam Ofen, ou Sam Pratt, cujo nome de nascimento era Yasgua, nativo de Nduro. Com a idade 22 anos ele foi vendido pelo chefe da cidade e, por volta de 1843, acabou transferido para a costa através do país Achanti. Nduro situava-se a sete dias de Rabba, a leste de Goali [Birnin Gwari?], sudoeste de "Hauçá", entre o país Kambali [Kambari] e Nupe. ${ }^{45}$ Outro dos informantes de Koelle, Habu, ou Sam Jackson, nasceu em Kano, na década de 1820. 
Quando tinha 20 anos, em algum momento da década de 30 do século XIX, foi agarrado em uma pilhagem de Gobir e vendido para o sul, em direção a Lagos. Semelhante era o caso de Mohammadu de Katsina, capturado pelos apresadores Fulani enquanto trabalhava em suas terras. Ele logo foi levado a Gobir e vendido a um comerciante de Damagaram, antes de ser enviado para o sul, em direção a Rabba, Ilorin, e finalmente para o litoral, provavelmente para Lagos. ${ }^{46}$

O Sargento Frazer, que em 1821 servia no Segundo Regimento das Índias Ocidentais em Serra Leoa, havia nascido na Hauçalândia "e por lá residiu muito tempo, [antes de ser] aprisionado em Goingia [Gonja] e trazido à Costa de Ouro, onde foi vendido". Frazer havia sido um comerciante que chegara a negociar em Borno. ${ }^{47}$ Ali Eisami foi agarrado durante a jihad em Borno, transportado através do Califado de Sokoto e vendido em Katunga (o nome Hauçá da capital de Oyo), mas seu senhor o revendeu à costa em 1817, pois temia que seu escravo pudesse estar envolvido na insurreição de escravos muçulmanos contra Oyo, naquele ano. ${ }^{48} \mathrm{Um}$ dos informantes de De Castelnau era Boué [Bawa?], vindo de Zaria, talvez na década de 30 do século XIX ou mesmo nos anos 40. Ele logo foi levado ao país Achanti, onde foi vendido a traficantes "europeus" (provavelmente portugueses). De Castelnau relata que a maioria dos cativos Hauçás alcançaram o litoral em Lagos, e não na Costa do Ouro, o que sugere que Boué encontrou seu caminho de volta através de Whydah ou de outro porto da Baía de Benin. ${ }^{49}$

Os seis escravos entrevistados por Menezes de Drumond, em 1819, tinham vindo de Nupe ou da Hauçalândia, mas todos haviam sido aprisionados durante a jih ad e chegaram à costa em Lagos ("Ico"). François era de Kano; Mathieu de Daura; Joseph de Tabarau, em Nupe; Bernard de Gobir; Benoit de Gaya [Ghuiah]; e Boniface de Kebbi. ${ }^{50}$ A época da deportação indica que eles eram prisioneiros da jihad e, embora nem todos pudessem ser muçulmanos, é provável que o fossem, ao menos superficialmente.

Como Clapperton informou de Wawa (Borgu) em 1826,

os escravos vendidos à costa são geralmente prisioneiros de guerra ou cativos domésticos rebeldes e intratáveis. Nyffé é, no momento, o lugar que produz a maioria destes escravos, devido à guerra civil que devasta o país. 
A guerra era a jihad, que redundava na derrocada da velha aristocracia local e no estabelecimento de um governo islâmico sob controle do Califado de Sokoto. ${ }^{51}$ Abali, que nasceu em Kanem, foi capturado durante uma invasão de Borno a Kano, onde foi vendido para o sul (Lagos) em 1844. ${ }^{52}$ Outro escravo, nascido em Kano, foi capturado em uma pilhagem em Gobir, "onde foi adquirido por traficantes e imediatamente levado para a costa através de Kadzina [Katsina], Zalia [Zaria], Nupe, Ilori [Ilorin], Dsebu [Ijebu], e Eko [Lagos]", também em 1844..$^{53}$ Do mesmo modo, Mohammadu (Jacob Brown) foi seqüestrado enquanto arava suas terras e logo vendido a Damagaram para, ao final, alcançar a costa através de Rabba e Ilorin, chegando em Serra Leoa em $1844 .{ }^{54}$

Se minhas estimativas do volume, idade e composição sexual da população escrava exportada forem razoavelmente precisas, talvez se possa concluir que o número de escravos adultos de sexo masculino disponíveis no Califado de Sokoto girava ao redor de 3 mil a 4 mil por ano durante a década de 20 do século XIX (não incluindo aí os Iorubas). A minoria destes ficava ali retida para emprego doméstico, mas a maioria era vendida para o sul e sudoeste. Alguns dos homens adultos exportados escaparam, morreram ou foram vendidos ao longo da rota, e outros foram mantidos no país Achanti, no Daomé e em estados Iorubas meridionais. Igualmente, foram retidas algumas mulheres e crianças exportadas também para o sul.

\section{A filiação religiosa da população deportada}

Os nomes constantes da amostragem que venho analisando oferecem uma indicação inicial acerca da filiação religiosa dos homens centro-sudaneses exportados. Dos 117 escravos, 41 ou bem possuíam nomes muçulmanos ou é quase certo que o fossem (cf. tabela 3). Doze cativos seguramente eram islâmicos, e quatro talvez, conclusão a que se chega através das declaraçôes de naturalidade. Trinta e sete cativos eram chamados por nomes cristãos e africanos, e não apresentavam indicação de serem, ou terem sido, muçulmanos. Apenas cinco tinham nomes cristãos, e três eram nomeados a partir de designações certamente africanas e não islâmicas. 


\section{Tabela 3: \\ Identificação religiosa dos escravos exportados do Sudão Central para a Costa da Guiné, 1805-1850}

\begin{tabular}{lcc}
\hline Nomes dos Escravos & NúMERO & PORCENTAGEM \\
\hline Muçulmanos & 41 & 40 \\
Seguramente muçulmanos & 12 & 12 \\
Talvez muçulmanos & 4 & 4 \\
Cristãos e africanos não-muçulmanos & 37 & 36 \\
Somente africanos & 3 & 3 \\
Somente cristãos & 5 & 5 \\
Sub-total & 102 & 100 \\
Sem indicação & 15 & \\
Total & 117 & \\
\hline
\end{tabular}

Fonte: Apêndice.

Embora não se saiba, dentre os escravos com nomes africanos nãomuçulmanos, quantos de fato eram islâmicos; nem quantos, entre detentores de nomes africanos e cristãos, também o fossem, é razoável concluir que pelo menos $56 \%$ dos centro-sudaneses eram islamizados. É possível que tal porcentagem fosse ainda mais alta.

Apesar desta análise de filiação religiosa de escravos e libertos centrosudaneses ser apenas preliminar, parece que o processo de conversão no Sudão Central, resultante da jihad, tinha continuidade na Bahia. Nomes muçulmanos eram adscritos a escravos de origem não-muçulmana, como "Keuta” [Kyauta], "So-Allah" [Filho de Alá] e "Meidassara” [Mai Nasara], indicando que alguns cativos haviam recebido rudimentos doutrinários islâmicos, normalmente oferecidos por ocasião da captura e venda. Os nomes africanos não islâmicos na origem incluíam escravos que claramente eram de origem Ioruba ou Nupe, sendo plausível que alguns deles fossem muçulmanos.

Entre os escravos e libertos arrolados por seu envolvimento na revolta Malê estavam vários clérigos muçulmanos (Hauçá: malam). Antônio, por exemplo, de origem Hauçá, freqüentara uma escola corânica antes de ser 
capturado. ${ }^{55}$ Reis realizou o estudo mais completo acerca destes religiosos, e Nina Rodrigues coletou informações sobre o imam que parece ter encabeçado a revolta. Samuel Crowther, que estava em Badagri em 1845, conheceu dois ex-escravos Hauçás do Brasil. Um deles, Mohama, era um malam, e travou com Crowther uma longa discussão teológica. ${ }^{56} \mathrm{O}$ cônsul francês em Salvador, Castelnau, entrevistou um velho Fulani na Bahia, em 1848, que certamente era um malam:

Este velho homem, Mohammed-Abdullad, Filani, que esteve na Bahia por cerca de trinta anos, obteve a liberdade através de seu próprio trabalho, e é hoje um carpinteiro. É educado e não apenas sabe ler e escrever em sua língua, mas também em português. Além disso, é muito intolerante, extremamente fanático, e quer converter-me por todos os meios. Embora eu o tratasse muito bem, dando-lhe dinheiro etc, ele recusou-se a ir à minha casa, dizendo para outro negro que não gostaria de adentrar a casa de um cão cristão. Ele aparentava ter setenta anos, era um marabout e tinha feito a peregrinação a Meca.... Fazia muitas piadas sobre Hauçás, dizendo que eles cultivam cavanhaque para parecerem homens. Originário de Kano, foi capturado em Katchina [Katsina] por Hauçás, contra quem os Filanis estavam em guerra naquele momento. Veio para a costa através da rota de [Lagos].... Os negros Hauçás da minha casa parecem ter muito respeito por este homem e, seguindo o seu exemplo, começam a sussurrar os versos do Alcorão. ${ }^{57}$

Dentre os amuletos, textos árabes e outros documentos capturados depois da revolta de 1835, incluíam-se rascunhos de estudantes e também trechos mais sofisticados do Alcorão. ${ }^{58}$ A presença de mesquitas e escolas corânicas foi assinalada na ocasião por autoridades, e posteriormente analisadas por numerosos pesquisadores. Como as atividades de clérigos muçulmanos deixavam claro, a resistência através de formas religiosas foi diretamente transferida da África para a Bahia na primeira metade do século XIX. Nina Rodrigues concluiu, em 1900, que a violência centrada na ideologia da jihad foi a base da resistência na Bahia. ${ }^{59}$

\section{Jihad e Resistência na Bahia}

O estudo das insurreições baianas entre 1807 e 1835 demonstra a complexidade dos problemas relativos ao controle social dos escravos. A 
resistência era inerente ao cativeiro, conforme reconheceu Eugene Genovese; ${ }^{60}$ mas um modelo explicativo calcado somente na experiência da Europa e da América do Norte por certo ensejará problemas. Como observou Jack Goody, o caso da Bahia não se ajusta aos modelos de Genovese sobre a resistência escrava nas Américas. ${ }^{61}$ As contradições internas ao cativeiro permitiram aos escravos estabelecer as suas próprias comunidades, mantendo um sentido de identidade como agentes culturais para, desse modo, resistir às incursões da cultura senhorial em suas vidas. Fatores africanos eram essenciais nesta busca de autonomia. Como afirmou John Thornton, até mesmo as práticas cristãs que, de maneira sincrética, emergiram na África, podiam ajudar a modelar as comunidades escravas das Américas. ${ }^{62}$

O contexto histórico no qual grupos específicos de escravos foram trazidos para as Américas tem que ser levado em consideração por qualquer tentativa de compreender a evolução da cultura e da sociedade escravistas. Dado ser geralmente difícil identificar as origens étnicas, religiosas e culturais dos cativos, os historiadores de escravidão americana têm tido dificuldades em avaliar o peso relativo da bagagem cultural que os escravos trouxeram da África para o desenvolvimento de sua cultura. Em alguns casos, porém, esta herança emerge com maior nitidez, como para a Bahia do início do século XIX.

A evolução da identidade Malê refletia a influência da luta ideológica e política na sociedade Hauçá em fins do século XVIII e inícios do seguinte. Os Hauçás encontraram-se escravizados nas Américas como resultado da convulsão política que precedeu a jih ad no Sudão Central; e novos desembarques depois da erupção da Guerra Santa, em 1804, reforçaram a ligação entre a evolução da África e a da diáspora, não só no Brasil como também em Serra Leoa. A identidade muçulmana emergiu como um laço predominante a unir os Hauçás e, por extensão, os escravos vizinhos originários de Borno e de Nupe. Pessoas de outras origens étnicas no Sudão Central parecem ter sido absorvidas pela comunidade muçulmana, não importando se eram ou não islamizados antes de deixar a África.

O afluxo de grandes quantidades de Iorubas muçulmanos desembarcados juntamente com Iorubas não-islamizados, resultou em uma "ioru- 
bização" da comunidade islâmica. Ao contrário da íntima associação estabelecida entre a identidade Hauçá e o islamismo, a correlação entre os Iorubas e o Islã nunca foi total. Ao que parece, escravos e libertos Iorubas às vezes se comportavam tendo por base o fundamento étnico propriamente dito; em outras, respondiam como muçulmanos. Os mais ortodoxos tenderam a ultrapassar a etnicidade, mas a adoração aos orixás permanecia forte, com o culto ogboni sendo especialmente vigoroso. Embora muitos Iorubas fossem muçulmanos, outros tantos não o eram, havendo ainda, em determinados contextos, a possibilidade de estabelecerem-se laços de solidariedade que tinham por base a identidade Ioruba e, portanto, a coalizão entre os Iorubas islamizados e não-islamizados. Disto resultavam duas tradições de revolta na Bahia — uma muçulmana e outra fundada nos orixás; a primeira transétnica e a segunda étnica. ${ }^{63}$

O senhores baianos tiveram que contar com uma população cativa (muçulmana ou não) importada da Baía de Benin, propensa à revolta e à ação militar. Muitos destes escravos trouxeram consigo uma tradição militar fundada na solidariedade religiosa e num compromisso com a Guerra Santa. Outros, originários da mesma regiāo, haviam sofrido, por um lado, os efeitos do Islã militante e, por outro, os que derivavam do fracasso da ação de não-muçulmanos e mesmo de islâmicos que se opunham à jihad. Os escravos e alforriados engajados nas conspiraçōes e insurreiçóes, que marcaram a escravidão baiana entre 1807 e 1835, procuravam forjar estratégias de resistência capazes de permitir um retorno seguro à África, ou a formação de comunidades autônomas no Brasil, ou ainda a própria superação do regime escravista. Em 1835, tendo o Islã por base, eles se aproximaram visando a destruição do sistema.

$\mathrm{Na}$ historiografia da escravidão, raramente foi possível correlacionar as trajetórias das sociedades de onde se originavam os cativos com os regimes escravistas americanos. No caso da Baía de Benin e da Bahia do século XIX, é possível rastrear numerosos escravos, desde a sua captura na África até a rebelião nas Américas; o caminho percorrido desde o Sudão Central e a Iorubalândia até a Baía de Benin, e dali, através do Atlântico, até a Bahia, onde suas ocupações, culturas e práticas religiosas são razoavelmente bem conhecidas. Quando a herança da população escrava baiana é examinada 
deste modo, as razões para a revolta e a habilidade para organizar a resistência à escravidão tornam-se mais claras.

Os perfis étnicos, etários e de gênero da população exportada da Baía de Benin ajudam a iluminar o debate sobre o papel da religião e da etnicidade nas várias conspiraçôes e insurreições da Bahia entre 1807 e $1835 .{ }^{64}$ Tais revoltas seguiram um padrão que sugere fortes semelhanças com a jihad que se alastrava pelo Sudão Central no mesmo período. Em 1835 havia uma bandeira, o uso de amuletos e de roupões muçulmanos brancos, a identificação através de nomes também islâmicos e orações grupais conduzidas por um imam. Fugas para os quilombos que rodeavam a cidade de Salvador também devem ser observadas; elas são congruentes com a hijra, embora não haja evidências de que os rebeldes percebiam os quilombos desta maneira. ${ }^{65}$

A congruência entre fatores próprios da esfera da demanda e da oferta criou uma situação explosiva: a demanda por homens adultos em idade produtiva, aptos ao uso em duras tarefas foi satisfeita, mas a oferta de adultos nestas condiçôes, geralmente prisioneiros de guerra, freqüentemente com treinamento e experiência militar, era perigosa, em especial quando eles se encontravam unidos ao redor de uma ideologia baseada na militância islâmica. Funcionários de governo e donos de escravos na Bahia debateram as políticas mediante as quais melhor poderiam prevenir outra revolução como a de Saint Domingue, sem reconhecer que a insurreição militar de soldados escravos em Ilorin (em 1817), e o contínuo envolvimento destes escravos na vida política de Oyo (na década de 1820) fornecia modelos de ação muito mais factíveis do que o gerado em Saint Domingue. A concentração de numerosos homens adultos levou a sociedade escravista baiana ao limite da revolta, e o Islã ofereceu aos cativos meios de superar as divisões étnicas. A jihad e as guerras a ela relacionadas constituíram uma experiência histórica compartilhada pela maioria dos escravos centro-sudaneses enviados para a Bahia, com a marcha forçada para a costa e a dura travessia oceânica em direção a solo baiano servindo para unir pessoas que, antes, poderiam até mesmo ter sido inimigas. O Islã alimentou a unidade destes escravos, como aliás Nina Rodrigues já reconhecia em $1900 .{ }^{66}$

Em comparação com outras fontes de escravos no Golfo de Benin e áreas adjacentes da costa da Guiné, o número total de escravos provenien- 
tes do interior e exportados através do Atlântico era relativamente pequeno. Mas como esses escravos do Sudão Central eram em sua maioria jovens do sexo masculino, alcançavam altos preços. Considerando o grande encarecimento dos homens levados do interior para os mercados costeiros, o tráfico deve ter sido muito lucrativo, o que sugere que pode ter havido boas oportunidades para a obtenção de lucros adicionais. ${ }^{67}$ Tais ganhos podiam realizar-se porque os "produtores" de escravos, a aristocracia do Sudão Central, transformavam os cativos — obtidos por meio de incursões e coleta de tributos, portanto, com custos atribuídos a outros objetivos de natureza política — em mercadoria de primeira, com preço significativamente mais alto na costa da Guiné do que no próprio Sudão Central. Na verdade, muitos adultos do sexo masculino eram mortos durante as incursões em vez de serem poupados para serem escravizados, uma indicação de que o valor, no campo de batalha, dos cativos adultos do sexo masculino era não apenas reduzido em relação ao preço local de jovens mulheres, mas em muitos casos era muito baixo, ou pelo menos mais baixo do que o custo adicional de preservar suas vidas. ${ }^{68}$

Por outro lado, os custos relativamente baixos dos homens adultos no Sudão Central sugerem que a sua oferta excedia a demanda. O tráfico para as Américas criou uma via de escoamento para este excedente de homens, os quais, do contrário, poderiam ter sido executados. A alta proporção de homens entre a população exportada do Sudão Central para o sul sugere que os comerciantes do interior respondiam à demanda dos traficantes europeus por cativos do sexo masculino. Este diferencial de preço era, por certo, claramente compreendido no Sudão Central. ${ }^{69}$

A alta proporção de homens entre os escravos exportados do Sudão Central para as Américas é ainda rara em vários sentidos. Ela é um traço diferencial quando comparada ao tráfico transatlântico em geral. De uma perspectiva centro-sudânica, a preferência dos entrepostos litorâneos do Atlântico por homens contrasta fortemente com o comércio transaariano de cativos, no qual as mulheres eram mais demandadas do que os homens, exceção feita aos eunucos. O Sudão Central exportou tipos distintos de escravos, homens adultos para o comércio atlântico e mulheres adultas e castrati para o comércio transaariano. Ao menos no caso do Sudão Cen- 
tral, parece que as demandas americana e norte-africana determinaram as taxas de masculinidade da população exportada. Também está claro que os comerciantes e funcionários centro-sudaneses, especialmente no Califado de Sokoto, tomavam decisões que pesavam no direcionamento de mulheres para o Norte da África, e de homens para as Américas. Neste caso, autoridades políticas dos Estados Nupes, Oyo e Hauçá no século XVIII, e do Califado de Sokoto no seguinte, procuraram deportar cativos masculinos capturados nas guerras, os quais, do contrário, poderiam ter sido executados. Por isso, por toda a costa da Baía de Benin podia-se encontrar escravos homens de boa qualidade fundamentalmente em função do comércio de reexportação do Sudão Central. O padrão de comércio demonstra uma clara divisão sexual no seio da população exportada. É evidente, pois, que os comerciantes no interior estavam extremamente atentos às diferentes demandas dos mercados externos das Américas e da África do Norte. O comércio de exportação de escravos do Sudão Central é um bom exemplo de um comércio determinado pela demanda, e não pela oferta.

Uma vez que se dissocie os dados relativos ao Sudão Central dos números de exportados através da Baía de Benin, observar-se-á que os vendedores de escravos daquela parte do litoral não foram capazes (ou não quiseram) prover o mercado americano com homens de origem local, ao menos na escala demandada pelas Américas. Escravos masculinos adultos centrosudaneses eram facilmente vendidos, mas nunca em quantidades suficientes para satisfazer os compradores europeus da costa e, por conseguinte, como notou Inikori, "os comerciantes europeus foram compelidos, através da competição entre eles, a comprar mais mulheres do que desejaram”, apesar "da forte preferência por escravos masculinos". ${ }^{70}$ Contudo, a população centro-sudanesa exportada para as Américas conformava o setor que mais se destacava na preferência dos compradores americanos. Os comerciantes litorâneos e os funcionários aparentemente utilizavam a reexportação do Sudão Central como meio de aumentar o componente masculino dos escravos que eles possuíam para a venda. Eles vendiam mulheres e crianças quando não havia homens suficientes, e estas mulheres e crianças quase sempre eram Iorubas. 
Apêndice:

Padrões gerais dos escravos exportados do Sudão Central, 1805-1850

\begin{tabular}{|c|c|c|c|c|c|c|}
\hline Nome & Sexo & Origem & Forma de Escravização & $\begin{array}{l}\text { Época da } \\
\text { Exportação }\end{array}$ & Rota para a Costa & Idade \\
\hline Dan Kano 5 & $M$ & Birnin Yauri & Pilhagem Fulani & 1804 & Achanti & Adulto \\
\hline Abubakar, Pasko ${ }^{4}$ & $\mathrm{M}$ & Gobir & Prisioneiro de guerra & c.1807 & Achanti & Desconhecida \\
\hline Boniface $^{1}$ & M & Kebbi & Guerra santa & $1804-08$ & Lagos & Adulto \\
\hline Benoit $^{i}$ & $\mathrm{M}$ & Gaya & Guerra santa & $1804-08$ & Lagos & Adulto \\
\hline François $^{1}$ & $M$ & Kano & Guerra santa & $1804-08$ & Lagos & Adulto \\
\hline Mathieu $^{1}$ & $\mathrm{M}$ & Daura & Guerra santa & $1804-08$ & Lagos & Adulto \\
\hline Bernard $^{1}$ & $\mathrm{M}$ & Gobir & Guerra santa & 1804-08 & Lagos & Adulto \\
\hline Mehemmet $^{2}$ & $\mathrm{M}$ & Kano & Guerra santa & c. 1810 & Desconhecida & 20 \\
\hline Gambo, Thomas King ${ }^{3}$ & $\mathrm{M}$ & Ngodsin & Desconhecida & 1810 & Desconhecida & Por volta de 20 \\
\hline Muhammadu & M & Gobir & Sequestro & 1810 & Desconhecida & 17 \\
\hline Andya, William Price ${ }^{3}$ & $\mathrm{M}$ & Jukun & Desconhecida & Década de 1810 & Desconhecida & 16 \\
\hline Damoutourou $^{2}$ & M & Borno & Guerra santa & Década de 1810 & Desconhecida & Adulto \\
\hline Francisco $^{1}$ (malam) & $\mathrm{M}$ & Hauçá & Desconhecida & Década de 1810 & Desconhecida & Adulto \\
\hline Mama, John Tanner ${ }^{3}$ & $\mathrm{M}$ & Nupe & Prisioneiro de guerra Fulani & 1816 & Lagos & 35 \\
\hline Keauta $^{3}[$ Kyauta $]$ & $\mathrm{M}$ & Kambari & Capturado pelos Fulani & 1816 & Rabba & 26 \\
\hline Luis Raimundo $^{8}$ & $\mathrm{M}$ & Hauçá & Desconhecida & 1817 & Desconhecida & Desconhecida \\
\hline Joseph $^{1}$ & M & Nupe & Guerra santa & Antes de 1818 & Lagos & Adulto \\
\hline Mohammad Abdullah $^{2}$ & $\mathrm{M}$ & Kano & Guerra santa & c. 1818 & Lagos & Adulto \\
\hline Musa Massause & $\mathrm{M}$ & Gwari & Guerra civil & 1818 & via Egba & 24 \\
\hline 'Ali Eisami William Harding ${ }^{3}$ & M & Kanuri & Pilhagem Fulani & 1818 & 'Aku' Iorubalândia & 25 \\
\hline Sarjeant Frazer ${ }^{5}$ & $\mathrm{M}$ & Hauçá & Sequestro & Antes de 1820 & Achanti & Adulto \\
\hline Elifo, Peter Mamma & $\mathrm{M}$ & Nupe & $\begin{array}{l}\text { Vendido, provavelmente } \\
\text { penhorado }\end{array}$ & 1820 & Lagos & 25 \\
\hline James Macaulay $^{6}$ & $\mathrm{M}$ & Nupe & Capturado pelos Fulani & 1820 & Rio Níger & \begin{tabular}{|l|} 
Adulto jovem \\
\end{tabular} \\
\hline $\begin{array}{l}\text { Sikari [Zakari] Thomas } \\
\text { Sawyer }^{3}\end{array}$ & $\mathrm{M}$ & Musu & Desconhecida & 1820 & Desconhecida & 20 \\
\hline Bilan, Andrew Rikett ${ }^{3}$ & $\mathrm{M}$ & Karekare & Desconhecida & 1820 & Desconhecida & 17 \\
\hline Mahammad, Manuel $^{2}$ & $\mathrm{M}$ & Katsina & Prisioneiro de guerra & c. 1820 & Lagos & Por volta de 20 \\
\hline James Macaulay & $\mathrm{M}$ & Mamagia, Nupe & Sequestro & 1820 & Niger & Desconhecida \\
\hline Kolo, John Gerber & $\mathrm{M}$ & Ebe, Nupe & Pilhagem Fulani & 1821 & Lagos & 27 \\
\hline Ndsu, John Macauly ${ }^{3}$ & $\mathrm{M}$ & Jukun & Prisioneiro de guerra & 1821 & Desconhecida & 17 \\
\hline Ogbaleye, Thomas Johnson & $\mathrm{M}$ & Ioruba, Oyo & Capturado pelos Fulani & 1822 & Lagos & 25 \\
\hline Batia, John William ${ }^{3}$ & $\mathrm{M}$ & Borgu & Guerra civil & 1822 & Desconhecida & Por volta de 20 \\
\hline desconhecido $^{7}$ & $\mathrm{M}$ & Borno & Guerra & 1824 & Whydah & Desconhecida \\
\hline Adsi, John Man $^{3}$ & $\mathrm{M}$ & Mbarike & Prisioneiro de guerra & 1824 & Rio Níger & Por volta de 40 \\
\hline Adsofe, William Davis ${ }^{3}$ & $\mathrm{M}$ & Eki, Bunu & Sequestro & 1824 & Rio Níger & Por yolta de 20 \\
\hline Concubine & $\mathrm{F}$ & Kano & Desconhecida & $1824-25$ & Lagos & Adulto \\
\hline Yono, William Macauly ${ }^{3}$ & $\mathrm{M}$ & Bfut & Prisioneiro de guerra Fulani & 1825 & Calabar & 18 \\
\hline Concubina & $\mathrm{F}$ & Kano & Desconhecida & 1826 & Lagos & Adulto \\
\hline Sobori, John Pratt & $\mathrm{M}$ & Esitako, Nupe & Pilhagem Fulani & 1826 & Rio Níger & 22 \\
\hline Ndanga, John Harding ${ }^{3}$ & M & Bakum & Prisioneiro de guerra Fulani & 1827 & Calabar & Por volta de 20 \\
\hline Mbepe, James John ${ }^{3}$ & $\mathrm{M}$ & Ngoala & Prisioneiro de guerra Fulani & 1827 & Calabar & 18 \\
\hline Awazi, Henry Johnson ${ }^{3}$ & $\mathrm{M}$ & Burukim & Prisioneiro de guerra Fulani & 1828 & Calabar & 20 \\
\hline Abutso, John Second ${ }^{3}$ & $\mathrm{M}$ & Afudu & $\begin{array}{l}\text { Sequestrado em pilhagem } \\
\text { escravista }\end{array}$ & 1828 & Rio Níger & 24 \\
\hline Paulo da Silva & $\mathrm{M}$ & Nupe & Desconhecida & Antes de 1830 & Desconhecida & Desconhecida \\
\hline Johnson $^{6}$ & $\bar{M}$ & Idah & Desconhecida & $\begin{array}{l}\text { Antes da década de } \\
1830\end{array}$ & Rio Níger & Desconhecida \\
\hline
\end{tabular}




\begin{tabular}{|c|c|c|c|c|c|c|}
\hline Adsoro $^{3}$ & M & Igbira & Sequestro & 1830 & Rio Níger & 22 \\
\hline Soraga, Thomas Cocker ${ }^{3}$ & $\mathrm{M}$ & Boritsu & Sequestro & 1830 & Rio Níger & 23 \\
\hline Disile, John Cocker ${ }^{3}$ & $\mathrm{M}$ & Tiv & Prisioneiro de guerra & 1830 & Rio Níger & $\begin{array}{l}\text { Adulto, com } 4 \\
\text { esposas }\end{array}$ \\
\hline William Dala ${ }^{3}$ & $\mathrm{M}$ & Bedde & Pilhagem Fulani & 1830 & 'Toruba' & 28 \\
\hline${\text { Karo, } \text { Manuel }^{2}}^{2}$ & $\mathrm{M}$ & Borno & Prisioneiro de guerra & Década de 1830 ? & Lagos & Adulto \\
\hline Ali Here $^{6}$ & M & Hauçá & Desconhecida & Antes de 1831 & Rio Níger & Desconhecida \\
\hline Atumei, Thomas Davis ${ }^{3}$ & $\mathrm{M}$ & Igbira (Panda) & Aprisionado & 1831 & Rio Níger & 30 \\
\hline Kamsi, John Thomas $^{3}$ & M & Balu & Prisioneiro de guerra Fulani & 1832 & Calabar & 20 \\
\hline desconhecido & $\mathrm{M}$ & Borno & Guerra santa & 1834 & Niger & Menino \\
\hline James Thomas & M & Bunu & Sequestro & 1834 & Niger & Desconhecida \\
\hline Magu, William Claudina & M & Eki, Taki town & Sequestrado pelos Kupa & Antes de 1835 & Niger & 23 \\
\hline Luis, Sanim & M & Nupe & Desconhecida & Antes de 1835 & Desconhecida & Desconhecida \\
\hline $\begin{array}{l}\text { Wosandse, }{ }^{3} \text { John } \\
\text { MacCormack }\end{array}$ & M & Kupa, Nupe & Contenda, vendido & 1835 & Rio Níger & Casado, 15 anos \\
\hline Ako, George Hall ${ }^{3}$ & $\mathrm{M}$ & Igbira (Panda) & Adultério & 1835 & Rio Niger & $30-35$ \\
\hline Sise, John Cole $^{3}$ & M & Bagba & Prisioneiro de guerra Fulani & 1835 & Calabar & 30 \\
\hline Robo, George Macauley & $\mathrm{M}$ & Yagba & Cativo de Nupe & 1835 & Lagos & 30 \\
\hline Aeta, Joseph Wilhelm. & $\mathrm{M}$ & Yagba & $\begin{array}{l}\text { Prisioneiro de guerra de Oyo, } \\
\text { Ioruba }\end{array}$ & 1835 & Lagos & 30 \\
\hline Arogu, James Jones & M & Yagba & Prisioneiro de guerra Fulani & 1836 & Lagos & Por volta de 20 \\
\hline Ate, Andrew Parker ${ }^{3}$ & M & Basa & Sequestro & 1837 & Rio Níger & Adulto, 3 esposas \\
\hline Aba-Hama ${ }^{2}$ & M & Borno & Prisioneiro de guerra & $\begin{array}{l}\text { Antes da década de } \\
1840\end{array}$ & Lagos & Adulto \\
\hline Soleman $^{2}$ & M & Borno & Prisioneiro de guerra & $\begin{array}{l}\text { Antes da década de } \\
1840\end{array}$ & Lagos & Adulto \\
\hline $\mathrm{Ali}^{2}$ & M & Borno & Prisioneiro de guerra & $\begin{array}{l}\text { Antes da década de } \\
1840\end{array}$ & Lagos & Adulto \\
\hline Aboubakar $^{2}$ & $\mathrm{M}$ & Bagirmi & Sequestro & $\begin{array}{l}\text { Antes da década de } \\
1840\end{array}$ & Lagos & Adulto \\
\hline Mammarou $^{2}$ & $\mathrm{M}$ & Muniyo Borno & Prisioneiro de guerra & $\begin{array}{l}\text { Antes da década de } \\
1840\end{array}$ & Lagos & Adulto \\
\hline Kiwa $^{2}$ & M & Zamfara & Prisioneiro de guerra & $\begin{array}{l}\text { Antes da década de } \\
1840\end{array}$ & Lagos & Adulto \\
\hline Hardou, Elias ${ }^{2}$ & M & Katsina & Capturado & $\begin{array}{l}\text { Antes da década de } \\
1840\end{array}$ & Nupe [Achanti ?] & Adulto \\
\hline desconhecido $^{6}$ & M & Kakanda & Desconhecida & Antes de 1840 & Desconhecida & Desconhecida \\
\hline desconhecido $^{6}$ & $\mathrm{M}$ & Borno & Desconhecida & Antes de 1840 & Desconhecida & Desconhecida \\
\hline Mahomed Lawina $^{6}$ & M & Fulani & Desconhecida & Antes de 1840 & Desconhecida & Desconhecida \\
\hline $\begin{array}{c}\text { desconhecido }^{3} \\
i=4\end{array}$ & M & Bedde & Desconhecida & $\begin{array}{l}\text { Antes da década de } \\
1840\end{array}$ & Desconhecida & Muito menino \\
\hline desconhecido $^{3}$ & $\mathrm{~F}$ & Bedde & Desconhecida & $\begin{array}{l}\text { Antes da década de } \\
1840\end{array}$ & Desconhecida & Muito menina \\
\hline desconhecido $^{3}$ & $\mathrm{~F}$ & Bedde & Desconhecida & $\begin{array}{l}\text { Antes da década de } \\
1840\end{array}$ & Desconhecida & Adulto \\
\hline $\operatorname{Rescou}^{2}$ & $\mathrm{M}$ & Nupe & Pilhagem Hauçá & $\begin{array}{l}\text { Início da década de } \\
1840\end{array}$ & Rabba & Adulto \\
\hline Boue, ${ }^{2}$ Antonio & M & Zaria & Prisioneiro de guerra & $\begin{array}{l}\text { Início da década de } \\
1840\end{array}$ & Nupe, Achanti & Adulto \\
\hline Odiemi, ${ }^{3}$ James Wilhelm & $\mathrm{M}$ & $\begin{array}{l}\text { Gori, NE } \\
\text { Ioruba Ijumu ou } \\
\text { Owe }\end{array}$ & Pilhagem Fulani e Nupe & $\begin{array}{l}\text { Início da década de } \\
1840\end{array}$ & Lagos & 28 \\
\hline Meidassara $^{2}$ [Mai Nasara] & $\mathrm{M}$ & Kano & Prisioneiro de guerra & $\begin{array}{l}\text { Início da década de } \\
1840\end{array}$ & Lagos & Adulto \\
\hline
\end{tabular}




\begin{tabular}{|c|c|c|c|c|c|c|}
\hline desconhecido $^{3}$ & $\mathrm{M}$ & Fika & Desconhecida & $\begin{array}{l}\text { Início da década de } \\
1840\end{array}$ & Desconhecida & Desconhecida \\
\hline desconhecido $^{3}$ & $\mathrm{M}$ & Fika & Desconhecida & $\begin{array}{l}\text { Início da década de } \\
1840\end{array}$ & Desconhecida & Desconhecida \\
\hline desconhecido ${ }^{3}$ & $\mathrm{~F}$ & Fika & Desconhecida & $\begin{array}{l}\text { Início da década de } \\
1840\end{array}$ & Desconhecida & Desconhecida \\
\hline desconhecido $^{3}$ & $\mathrm{~F}$ & Fika & Desconhecida & $\begin{array}{l}\text { Início da década de } \\
1840\end{array}$ & Desconhecida & Desconhecida \\
\hline Griss, Quacho ${ }^{2}$ & M & Lafia & Prisioneiro de guerra & $\begin{array}{l}\text { Início da década de } \\
1840\end{array}$ & Desconhecida & Adulto \\
\hline Bague $^{2}$ & $\mathrm{M}$ & Nupe & Desconhecida & $\begin{array}{l}\text { Início da década de } \\
1840\end{array}$ & Desconhecida & Adulto \\
\hline $\mathrm{Ali}^{3}$ & $\mathrm{M}$ & Muniyo & Desconhecida & $\begin{array}{l}\text { Início da década de } \\
1840\end{array}$ & Desconhecida & Desconhecida \\
\hline Ibrahim $^{2}$ & M & Hauçá & Desconhecida & Década de 1840 & Desconhecida & Jovem \\
\hline Runaway Slave $^{5}$ & $\mathrm{M}$ & Borno & Desconhecida, sequestro & Antes de 1841 & Achanti & Desconhecida \\
\hline Adam, $\mathrm{Braz}^{2}$ & $\mathrm{M}$ & Zaria & Prisioneiro de guerra & Década de 1840? & Lagos & Adulto \\
\hline Wuene, ${ }^{3}$ William Cole & $\mathrm{M}$ & Borgu & Guerra com Ilorin & 1842 & Ioruba & 25 \\
\hline Mahammah Manuel $^{2}$ & $\mathrm{M}$ & Kano & Prisioneiro de guerra & c. 1842 & Lagos & Adulto \\
\hline Yasqua Ofen, Sam Pratt ${ }^{3}$ & $\mathrm{M}$ & Gwari & Vendido pelo chefe & 1843 & Achanti & 22 \\
\hline Segbara, Thomas Cocker ${ }^{3}$ & $\mathrm{M}$ & Basa & Prisioneiro de guerra & 1843 & Rabba & 24 \\
\hline Abarsi, Andrew Aitkin ${ }^{3}$ & $\mathrm{M}$ & Tuareg & Sequestro & 1843 & Desconhecida & 28 \\
\hline Ali, Moses Twin ${ }^{3}$ & $\mathrm{M}$ & Bedde & Desconhecida & 1844 & Desconhecida & 17 \\
\hline Madsinda, Thomas Cocker ${ }^{3}$ & M & Kamuku & Penhora & 1844 & Desconhecida & 25 \\
\hline desconhecido $^{3}$ & M & Fika & Desconhecida & 1845 & Desconhecida & 23 \\
\hline desconhecido $^{3}$ & M & Fika & Desconhecida & 1846 & Desconhecida & 29 \\
\hline Dsetham, George Harding ${ }^{3}$ & $M$ & Jaba & Prisioneiro de guerra & 1846 & Desconhecida & 23 \\
\hline Gbala, Sam John ${ }^{3}$ & $\mathrm{M}$ & Koro & Prisioneiro de guerra & 1846 & Desconhecida & 19 \\
\hline Abare, Andrew Sewell ${ }^{3}$ & M & Karekare & Desconhecida & 1846 & Desconhecida & 18 \\
\hline $\mathrm{Habu}^{3}{ }^{3}$ Andrew Sewell ${ }^{3}$ & $\mathrm{M}$ & Kano & Prisioneiro de guerra & 1846 & Lagos & 20 \\
\hline Made $^{3}$ & $\mathrm{M}$ & Muniyo & Sequestro & 1846 & Desconhecida & Por volta de 20 \\
\hline Muhammadou, Jacob Brown ${ }^{3}$ & $M$ & Katsina & Sequestro & 1846 & Ilorin & Por volta de 20 \\
\hline $\mathrm{Abali}^{3}$ & $\mathrm{M}$ & Kanem & Prisioneiro de guerra & 1846 & Lagos & 22 \\
\hline Albarka $^{3}$ & $M$ & Jarawa & Tributo & 1847 & Desconhecida & 12 \\
\hline Adamu, Edward Klein ${ }^{3}$ & M & Kano & Prisioneiro de guerra & 1847 & Desconhecida & Por volta de 20 \\
\hline Momadu, Robert Dixon ${ }^{3}$ & $\mathrm{M}$ & Nguru & Desconhecida & 1847 & Desconhecida & 26 \\
\hline Gol, Thomas Klein ${ }^{3}$ & M & Bute & Prisioneiro de guerra Fulani & 1847 & Lagos & 19 \\
\hline Desconhecido & M & Bute & Prisioneiro de guerra Fulani & 1847 & Lagos & Muito menino \\
\hline desconhecido & $\mathrm{F}$ & Bute & Prisioneiro de guerra Fulani & 1847 & Lagos & Muito menina \\
\hline Lamadsi, John Smith ${ }^{3}$ & M & Gwari & Sequestro, pilhagem Fulani & 1847 & Rabba & 47 \\
\hline Desconhecido & $\mathrm{M}$ & Lafia Hauçá & Capturado & 1847 & [Lagos] & Menino \\
\hline So-Allah, [Son Allah] David ${ }^{2}$ & $\overline{\mathrm{M}}$ & Tangali & Criança escrava (penhorado?) & 1850 & Lagos & 10 \\
\hline Osman, Francisco ${ }^{2}$ & $\mathrm{M}$ & Shira & Sequestro & 1850 & Lagos & Por volta de 20 \\
\hline Grusa, Augusto $^{2}$ & $\mathrm{M}$ & Zaria & Escravo doméstico & 1850 & Lagos & Adulto \\
\hline
\end{tabular}

\section{Fontes:}

(1) DRUMOND, Menezes de. "Lettres sur l'Afrique ancienne et moderne". In: Journal des Voyages, 32, 1826, pp. 205-16.

(2) CASTELNAU, Francis de. Renseignements sur l'Afrique centrale et sur une nation d'hommes a queue qui s'y trouverait, d'apres le rapport des negres du Soudan, esclaves a Bahia. Paris: P. Bertrand, 1851. 
(3) KOELLE, Sigismund Wilhelm. Polyglotta Africana. Graz: Akademische Drucku. Verlagsanstalt 1963, pp. 8-18.

(4) LANDER, Richard. Records of Captain Clapperton's Last Expedition to Africa. London: Colburn and Bentley, 1830, vol. I, pp. 204, 206.

(5) MISRAH, Muhammad. "Narrative of a Journey from Egypt to the Western Coast of Africa, by Mahomed Misrah. Communicated by an Officer serving in Sierra Leone". In: The Quarterly Journal, October 1822, 6, pp. 15-16.

(6) ALLEN, William e THOMSON, T. R. H. A Narrative of the Expedition sent by Her Majesty's Government to the River Niger in 1841, under the Command of Captain H.D. Trotter, R.N. London: Bentley, 1848, vol. I, pp. 79, 252 e 330; e vol. II, pp. 117-18 e 184.

(7) DUNCAN, John. Travels in Western Africa, in 1845 and 1846. London:Bentley, 1847, vol. II, p. 175.

(8) VERGER, Pierre. Trade Relations between the Bight of Benin and Bahia from the $17^{\text {th }}$ to the $19^{\text {th }}$ Century. Ibadan: University of Ibadan Press, 1976, p. 434.

\section{Notas}

${ }^{1}$ Cf., por exemplo, dentre os trabalhos de Pierre Verger, especialmente Trade Relations between the Bight of Benin and Bahia from the $17^{\text {th }}$ to the $19^{\text {th }}$ Century. Ibadan: University of Ibadan Press, 1976; REIS, João. Slave Rebellion in Brazil: The Muslim Uprising of 1835 in Bahia. Baltimore: Johns Hopkins University Press, 1993; SCHWARTZ, Stuart. Sugar Plantations in the Formation of Brazilian Society: Bahia, 1550-1835. Cambridge: Cambridge University Press, 1985; MATTOSO, Kátia de Queirós. Babia Século XIX: Uma Provincia no Império Rio de Janeiro: Nova Fronteira, 1992; OLIVEIRA, Maria Inês Côrtes de. Retrouver une identité: Jeux sociaux des Africains de Bahia: (vers 1750 - vers 1890). Tese de doutorado, Université de Paris-Sorbonne (Paris IV), 1992; NISHIDA, Mieko. "Manumission and Ethnicity in Urban Slavery: Salvador, Brazil, 1808-1888". In: Hispanic American Historical Review, 73:3, 1993, pp. 361-91.

${ }^{2}$ Cf., dentre meus estudos anteriores, "Background to Rebellion: The Origins of Muslim Slaves in Bahia". In: Slavery and Abolition, 15, 2, 1994, pp. 151-82; e "The Central Sudan and the Atlantic Slave Trade". In: HARMS, Robert W. et al. Paths toward the Past: African Historical Essays in Honor of Jan Vansina. Atlanta: African Studies Association Press, 1994, pp. 345-70. A amostragem preliminar foi completada com outros dez casos; todavia, na amostra anterior um indivíduo foi contado duas vezes, e este erro, alertado por Robin Law, foi corrigido. Observe-se ainda que a presente amostragem será completada com biografias adicionais, baseadas em fontes brasileiras, especialmente baianas. Uma pesquisa inicial dos registros judiciais gerados pela insurreição de 1835 na Bahia oferece maior detalhamento sobre as origens dos indivíduos, embora se espere que levantamentos arquivísticos adicionais esclareçam melhor a questão. Sou grato a Marcia Smith pelo exame dos registros judiciários publicados (veja-se "The Male Uprising in Bahia, 1835: Mini- 
Biographies of Leaders and Others Accused”, 1998 (paper inédito, seminário na York University).

${ }^{3}$ No caso das pessoas que acabaram em Serra Leoa, suas biografias derivam de entrevistas feitas por d'Andrada, um antigo ministro do governo brasileiro, autor de um ensaio sobre a geografia de Portugal (1819), conforme o que foi reportado por Menezes de Drumond (7 casos); do material coletado pelos membros da Expedição ao Níger em 1841 (6 casos); as narrativas de escravos coletadas por Francis de Castelnau, cônsul francês na Bahia, em fins da década de 1840 (23 casos); o inventário linguístico realizado por Sigismund Wilhelm Koelle em 1850, com ex-escravos (66 casos); além do material derivado de diversas outras fontes (15 casos). Cf. as indicações de fontes no apêndice em anexo.

${ }^{4}$ LOVEJOY, Paul E. "The Clapperton-Bello Exchange: The Sokoto Jihad and the TransAtlantic Slave Trade, 1804-1837”. In: WILLEY, A. Elizabeth e WISE, Christopher (eds.). The Desert Shore: Literatures of the African Sahel. Boulder Col.: Lynn Reiner, 2000. Cf. tb. FISHER, Humphrey. "A Muslim Wilberforce? The Sokoto Jihad as Anti-Slavery Crusade: An Enquiry into Historical Causes”. In: DAGET, S. (ed.). De la traite à l'esclavage du Ve au XIX ${ }^{\text {eme }}$ siecle. Nantes:Centre de Recherche sur l'Histoire du Monde Atlantique, 1985, vol. II, pp. 537-55.

${ }^{5}$ LOVEJOY, ““The Central Sudan...”, op. cit., pp. 351-55. Cf. tb. ELTIS, David; RICHARDSON, David; BEHRENDT, Steven e KLEIN, Herbert. The Atlantic Slave Trade: A Database in CD-Rom. Cambridge:Cambridge University Press, 1999.

${ }^{6}$ KOLAPO, James Femi. Military Turbulence, Population Displacement and Commerce on a Trading Frontier of the Sokoto Caliphate: Nupe c. 1810-1857. Tese de doutorado, York University, 1999.

${ }^{7}$ Patrick Manning, usando um método distinto, chegou a uma estimativa ao menos comparável, concluindo que 93 mil escravos Hauçás e Nupes foram exportados da Baía de Benin nos séculos XVIII e XIX. De acordo com suas projeções, tal movimento incluía 22 mil escravos Nupes entre a década de 1740 e a de 1860, e 70.800 Hauçás entre a década de 1780 s e a de 1860. Cf. o seu Slavery, Colonialism and Economic Growth in Dahomey, 1640-1960. Cambridge: Cambridge University Press, 1982, Apêndice 2. Observe-se que Manning oferece totais ligeiramente menores para as exportações de Hauçás e Nupes na página 31. Dado o não refinamento dos números e o fato de Manning não incluir escravos não-Hauçás e não-Nupes, suas estimativas são bastantes próximas às minhas.

${ }^{8}$ MANNING, Patrick. "The Slave Trade in the Bight of Benin, 1640-1890". In: GEMERY, Henry e HOGENDORN, Jan (eds.). The Uncommon Market: Essays in the Economic History of the Atlantic Slave Trade. New York:Academic Press, 1979, p. 127.

${ }^{9}$ LAW, Robin. The Oyo Empire c. 1600-c. 1836. Oxford:Oxford University Press, 1977, p. 217; e, do mesmo autor, "Slave-raiders and Middlemen, Monopolists and Free-traders: the Supply of Slaves for the Atlantic Trade in Dahomey, c. 1715-1850". In: Journal of African History, 30, 1989, pp. 45-68. 
${ }^{10}$ Sobre Pierre Tamata, veja-se VERGER, op. cit., pp. 186-90. Cf. tb. ADAMS, John. Remarks on the Country extending from Cape Palmas to the River Congo. London:G. and W.B. Whittaker, 1823, pp. 82-87.

${ }^{11}$ Adams, que comerciou ao longo da Costa de Guiné nas décadas de 1780 e 1790, notou nunca haver encontrado escravos Hauçá ou outros quaisquer do Sudão Central em Bonny. Ele confiou em sua experiência para erroneamente demonstrar que o Rio de Níger não poderia desaguar no Golfo de Guiné. De acordo com o seu raciocínio, ele deveria ter achado escravos do interior nos portos do Delta, tal como o fez em Lagos. CfCf. ADAMS, Remarks, op. cit., pp. 220-2. De modo semelhante, não tenho conhecimento de qualquer registro de escravos do Sudão Central que tenham sido embarcados na Costa do Ouro no século 18. ${ }^{12}$ Conde da Ponte, Governador da Bahia, despacho de 16 de junho de 1807, conforme citado em VERGER, op. cit., p. 17.

${ }^{13}$ De acordo com Schwartz, os Iorubas, Ewes e Hauçás constituíam um terço da população escrava da Bahia no início do século XIX em função das por então recentes importações - cf. Sugar Plantations, op. cit., pp. 437, 475.

${ }^{14}$ FO 84/9 e 15, como citado por ELTIS, David. Economic Growth and the Ending of the Transatlantic Slave Trade. New York: Cambridge University Press, 1987, p. 358.

${ }^{15}$ REIS, op. cit., p. 140. Os cativos e ex-escravos acusados de envolvimento na rebelião de 1835 eram predominantemente Iorubas e muçulmanos, não sendo, portanto, representativos da população escrava e liberta como um todo.

${ }^{16}$ KOELLE, Sigismund Wilhelm. Polyglotta Africana. Graz:Akademische Druck-u. Verlagsanstalt 1963, pp. 1-21; HAIR, P. E. H. "Koelle at Freetown: an historical introduction," In: KOELLE, op. cit., pp. 7-17; HAIR, P. E. H. "The enslavement of Koelle's informants". In: Journal of African History, vI, 1965, pp. 193-203. Os números entre parênteses referem-se à população mencionada para cada grupo linguístico.

${ }^{17}$ CURTIN, Philip D. The Atlantic Slave Trade: A Census. Madison:University of Wisconsin Press, 1969, p. 244. Curtin, que compilou os censos a partir dos Parliamentary Papers, 1849 [C.1126], inclui escravos originários de Nupe na Baía de Benin e cativos Hauçás na Baía de Biafra, embora seja muito provável que a maioria dos Hauçás transitassem por portos da Baía de Benin, não na Baía de Biafra.

${ }^{18}$ CURTIN, op. cit., pp. 244-49, 289-98. Cf. tb. CURTIN, Philip D. e VANSINA, Jan. "Sources of the nineteenth-century Atlantic slave trade". In: Journal of African History, v, 1964, pp. 185-208. Para ex-escravos Hauçás e Nupes de Serra Leoa cf. FYFE, Christopher. A History of Sierra Leone. London: Oxford University Press, 1962, pp. 66, 138, 170, 231, 234, 424 (Hauçás), e 170, 231, 289, 293, 320 (Nupes).

19 SHIELDS, Francine. Palm Oil and Power: Women in an Era of Economic and Social Transition in 19th Century Yorubaland (South-western Nigeria)". Tese de doutorado, Stirling, 1997, pp. 296-303; da mesma autora, "Those Who Remained Behind: Women Slaves in Nineteenth-Century Yorubaland”. In: Lovejoy, Paul E. (ed.), Identity in the Shadow of Slavery. London:Cassell Academic, 2000; e KOLAPO, op. cit., 
${ }^{20}$ O'HEAR, Ann. Power Relations in Nigeria: Ilorin Slaves and their Successors. Rochester: University of Rochester Press, 1997.

${ }^{21}$ GEGGUS, David. "Sex Ratio, Age and Ethnicity in the Atlantic Slave Trade: Data from the French Shipping and Plantation Records". In: Journal of African History, 30, 1989, p. 36. ${ }^{22}$ Idem, Ibidem. Geggus detecta 227 escravos "Aussa” com uma razão de masculinidade da ordem de 1.521:100; e 60 "Gambari” (o termo ioruba para Hauçá) com uma razão de 1.900:100. Recalculei seus os números para estabelecer a porcentagem de homens centro-sudaneses como um todo.

23 “Clapperton para R. Wilmot Horton, 6 de Junho de 1825”. In: BOVILL, E. W. (ed.). Missions to the Niger, IV. The Bornu Mission, 1822-25, Part 3. London: Cambridge University Press, 1966, vol. IV, p. 774.

${ }^{24}$ CASTELNAU, Francis de. Renseignements sur l'Afrique centrale et sur une nation d'hommes a queue qui s'y trouverait, d'apres le rapport des negres du Soudan, esclaves a Bahia. Paris:P. Bertrand, 1851, p. 9. Eles "viennent a peu pres tous par la voie d'Onim [Lagos]".

${ }^{25}$ RICHARDSON, James. Narrative of a Mission to Central Africa performed in the Years 1850-51. London:Chapman and Hall, 1853, vol. II, p. 203.

${ }^{26}$ TAMBO, David Carl. "The Sokoto Caliphate Slave Trade in the Nineteenth Century". In: International Journal of African Historical Studies, 9, 2, 1976, pp. 204-205. Entre outras fontes, Tambo cita a correspondência de Davies para Campbell, de 31 de janeiro de 1858 (FO 541).

${ }^{27}$ FYFE, op. cit., p. 212.

${ }^{28}$ LOVEJOY, Paul E. "Concubinage in the Sokoto Caliphate (1804-1903)”. In: Slavery and Abolition, XI, 1990, pp. 158-89.

${ }^{29}$ ELTIS, David e ENGERMAN, Stanley. "Was the Slave Trade Dominated by Men?”. In: Journal of Interdisciplinary History, 23, 1992, p. 255.

${ }^{30}$ ELTIS, David. "Fluctuations in the Age and Sex Ratios of Slaves in the NineteenthCentury Transatlantic Slave Traffic”. In: Slavery and Abolition, 7, 1986, pp. 257-72; ELTIS e ENGERMAN, "Was the..., op. cit., pp. 237-57; GEGGUS, op. cit., p. 28; LOVEJOY, Paul E. "The Impact of the Atlantic Slave Trade on Africa: A Review of the Literature", Journal of African History, 30, 1989, p. 378.

${ }^{31}$ ELTIS, Economic Growth, op. cit., p. 358.

${ }^{32}$ Entre outras fontes, cf. LA TORRE, Joseph Raymond. Wealth Surpasses Everything: An Economic History of Asante in the Nineteenth Century. Tese de doutorado, Universidade da Califórnia, 1978. A análise de que La Torre faz dos registros de recrutamento holandeses está calcada na associação entre "Marabu" e Hauçá — o que me parece uma suposição razoável.

33 "B. Campbell para Clarendon, 27 de março de 1858", como mencionado em ELTIS, Economic Growth, op. cit., p. 358. 
${ }^{34}$ AGIRI, Babatunde. "Slavery in Yoruba Society in the 19th Century". In: LOVEJOY, Paul E. (ed.). The Ideology of Slavery in Africa. Beverly Hills:Sage Publications, 1981, pp. $141-2$.

35 "Clapperton para Horton, 6 de junho de 1825", cit. por BOVILL, op. cit., p. 774.

${ }^{36}$ MANNING, Patrick. Slavery and African Life: Occidental, Oriental and African Slave Trades. Cambridge: Cambridge University Press, 1990, p. 98.

${ }^{37}$ Cf., por exemplo, MASON, Michael. "Population and 'Slave Raiding' - The Case of the Middle Belt of Nigeria”. In: Journal of African History, 10, 4, 1969, pp. 551-64; e HOGENDORN, Jan. "Slave Acquisition and Delivery in Precolonial Hausaland". In: DUMETT, R. e SCHWARTZ, Ben K. (eds.). West African Culture Dynamics: Archaeological and Historical Perspectives. The Hague, 1980, pp. 477-93; cf. tb., BURNHAM, Philip. "Raiders and traders in Adamawa: slavery as a regional system". In: WATSON, James L. (ed.), Asian and African Systems of Slavery. Oxford:Oxford University Press, 1980, pp. 43-72.

${ }^{38}$ DUNCAN, John. Travels in Western Africa, in 1845 and 1846. London:Bentley, 1847, vol. I, pp. 64, pp. 185-86.

${ }^{39}$ Idem, vol. II, p. 175.

${ }^{40}$ CLAPPERTON, Hugh. Journal of a Second Expedition into the Interior of Africa. London:John Murray, 1829, p. 171.

${ }^{41}$ Idem, p. 95.

${ }^{42}$ MISRAH, Muhammad. "Narrative of a Journey from Egypt to the Western Coast of Africa, by Mahomed Misrah. Communicated by an Officer serving in Sierra Leone". In: The Quarterly Journal, October 1822, 6, p. 14.

${ }^{43}$ LANDER, Richard. Records of Captain Clapperton's Last Expedition to Africa. London: Colburn and Bentley, 1830, vol. I, pp. 204, 206.

${ }^{44}$ Conforme informado por MISRAH, op. cit., p. 6.

${ }^{45}$ KOELLE, op. cit., p. 19.

${ }^{46}$ Idem, p. 17.

${ }^{47}$ Conforme informado por MISRAH, op. cit., pp. 15-16.

${ }^{48}$ Cf. a biografia Ali Eisami, que foi capturado durante a jihad em Borno, em CURTIN, Philip D. (ed.), Africa Remembered: Narratives of West Africans from the Era of the Slave Trade. Madison:University of Wisconsin Press, 1967, pp. 202, 211-12.

${ }^{49}$ CASTELNAU, op. cit, p. 40.

${ }^{50}$ DRUMOND, Menezes de. "Lettres sur l'Afrique ancienne et moderne". In: Journal des Voyages, 32, 1826, pp. 205-16.

${ }^{51}$ CLAPPERTON, op. cit. p. 94.

${ }^{52}$ KOELLE, op. cit., p.10.

${ }^{53}$ Idem, p. 17. 
${ }^{54}$ Idem, Ibidem.

${ }^{55}$ REIS, op. cit., pp. 102-103 (cf. tb. a versão ainda em formato tese, com título semelhante, defendida na University of Minnesota em 1983, pp. 146-47).

${ }^{56}$ Crowther, na abertura de seu diário, em 12 de junho de 1846, declara que ele e Townsend foram para Badagri "to see the extension of Indian corn, beans, groundnuts, and cassava belonging to the Hausa people. Since last month, I have visited many similar plantations. All this cultivation began this year because when we arrived here [em meados de 1845] there was no sign of cultivation anywhere in or around Badagri”; CMS, Yoruba Mission, CA2/031(b). Cf. tb. ADAMU, Mahdi. The Hausa Factor in West African History. Zaria e Ibadan, Ahmadu Bello University Press e Ibadan University Press, 1978, pp. 128, 132.

${ }^{57}$ CASTELNAU, op. cit, p. 46. Cf. tb. VERGER, op. cit., p. 287.

${ }^{58}$ Cf. GOODY, Jack. "Writing, Religion and Revolt in Bahia”. In: Visible Language, 20, 1986, pp. 318-43; MONTEIL, Vincent. "Analyse de 25 documents arabes des Males de Bahia (1835)". In: Bulletin de l'Institute Fondamaentale d'Afrique Noire, ser. B, 29, 1-2, 1967, pp. 88-98; e REICHERT, Rolf. "L'insurrection d'esclaves de 1835 a la lumiere des documents arabes des archives publiques del'etat de Bahia (Bresil)". In: Bulletin de l'Institute Fondamaentale d'Afrique Noire, ser. B, 29, 1-2, 1967, pp. 99-104.

${ }^{59}$.Raymundo Nina Rodrigues publicou sua análise preliminar acerca da importância do Islam entre os escravos no Jornal do Commércio (Rio de Janeiro, 2 de Novembro de 1900); cf. VERGER, op. cit., pp. 285-86. Para o trabalho completo cf. RODRIGUES, Raymundo Nina. Os Africanos no Brasil. Brasília:Editora da Unb, 1988, baseado em notas coletadas entre 1890 e o ano de sua morte (1906). Para uma crítica de Nina Rodrigues, cf. REIS, op. cit., pp. 120-28.

${ }^{60}$ GENOVESE, Eugene. From Rebellion to Revolution: Afro-American Slave Revolts in the Making of the New World. Baton Rouge:Louisiana State University Press, 1979. Cf. tb. CRATON, Michael. Testing the Chains: Resistance to Slavery in the British West Indies. Ithaca:Cornell University Press, 1982.

${ }^{61}$ GOODY, op. cit., p. 331.

${ }^{62}$ THORNTON, John. Africa and Africans in the Making of the Atlantic World, 14001680. Cambridge, Cambridge university Press, 1992.

${ }^{63} \mathrm{Na}$ década de 1820 ocorreram 10 rebeliōes na Bahia e cinco em Sergipe de El-Rey, nas quais cativos e ex-escravos Iorubas estiveram envolvidos (cf. SCHWARTZ, op. cit., pp. 486-87).

${ }^{64}$ Cf., por exemplo, SCHWARTZ, Stuart. "Cantos e quilombos numa conspiração de escravos hauçás - Bahia, 1814,” in REIS, João José e GOMES, Flavio dos Santos (eds.). Liberdade por um Fio: Historia dos quilombos no Brasil. São Paulo:Companhia das Letras, 1996.

${ }^{65}$ RODRIGUES, op. cit., passim. É difícil imaginar que os muçulmanos do Sudão Central da época não pudessem perceber a resistência em termos de jihad, mas a questão está longe de ser resolvida. REIS demonstra que a revolta de 1835, em particular, foi um le- 
vante muçulmano, mas sugere, por exemplo, que não se tratou de uma jihad (Cf. Slave Rebellion, op. cit. passim). Para uma interpretação que em grande parte dissolve o fator muçulmano cf. KENT, Raymond, "African Revolt in Bahia”. In: Journal of Social History, 3, 1970, pp. 334-56.

${ }^{66}$ RODRIGUES, op. cit., passim; cf. tb. VERGER, op. cit.

${ }^{67}$ Cf. LOVEJOY, Paul E. e RICHARDSON, David. "Competing Markets for Male and Female Slaves: Slave Prices in the Interior of West Africa, 1780-1850”, In: International Journal of African Historical Studies, 28,2, 1995, passim; MANNING, Slavery and African, op. cit., pp. 65-6.

${ }^{68}$ Segundo Dixon Denham, escrevendo de Borno em 26 de abril de 1822, as por então recentes pilhagem tinham tido tanto êxito "that unable to keep all, they massacred the men, being of the least value, and most troublesome" (cit. em BOVILL, op. cit., vol. III, p. 553).

${ }^{69}$ De acordo com informações recolhidas por Denham em Borno (1822), "at eight days' distance only from Yeouri [Yauri, no Níger], large boats came to a place called Yearban [Yoruba], but it is not on the bahr kebir. Katungah [Katunga, i.e., Oyo] is the great port, which is at some distance: to both of these places people he called Americans came; they were white, and Christians: they always demand gum arabic and male slaves, for which they will pay as high as sixty to seventy dollars each". Este relato é ainda mais valioso na medida em que Denham não compreendia que o Níger fluía para o Golfo da Guiné e, conseqüentemente, que havia uma rota fluvial direta do norte para o sul. Cf. DENHAM, Dixon; CLAPPERTON, Hugh e OUDNEY, Walter. Narrative of Travels and Discoveries in Northern and Central Africa, in the Years 1822, 1823, and 1824. London: John Murray, 1828, vol. II, pp. 91-2.

${ }^{70}$ INIKORI, Joseph E. "Export versus domestic demand: the determinants of sex ratios in the Transatlantic slave trade". In: Research in Economic History, 14, 1992, p. 155.

\section{Resumo}

A CONFIGURAÇÃO ÉTNICA da população baiana modificou-se bastante de fins do século XVIII para o século seguinte, quando povos islâmicos africanos tornaram-se comuns entre os escravos, em especial a partir dos grandes desembarques de cativos de fala Ioruba. As origens desses muçulmanos podem estar relacionadas ao contexto próprio das áreas interioranas da Baía de Benin e à jihad do Xeque Usman dan Fodio, fundador do Califado de Sokoto. Este estudo examina o material biográfico disponivel, procurando oferecer subsidios adicionais acerca da comunidade muçulmana para, assim, estabelecer mais claramente as ligaçôes entre os padrões de resistência à escravidão na Bahia, que culminaram na insurreição Malê de 1835, e o movimento da jihad no interior da Baía de Benin. 
$44 \cdot$ T O Р O

\section{Abstract}

THE ORIGINS OF MUSLIM slaves in Babia can be traced to the interior of the Bight of Benin and the jihad of Sheikh Usman dan Fodio that established the Sokoto Caliphate. As is well known, the ethnic configuration of the Bahian population changed significantly in the last decades of the eighteenth century and continuing into the nineteenth, as Hausa, Nupe, and other Muslims became more common among the slaves, and most especially with the massive arrival of Yoruba-speaking slaves in the nineteenth century. The present study examines available biographical material in an attempt to shed additional light on the Muslim community and thereby establish more clearly the links between the patterns of resistance to slavery in Bahia, culminating in the Male uprising of 1835, with the jihad movement in the interior of the Bight of Benin. 